\title{
Marine omega-3 fatty acids prevent myocardial insulin resistance and metabolic remodeling as induced experimentally by high insulin exposure
}

Citation for published version (APA):

Franekova, V., Angin, Y., Hoebers, N. T. H., Coumans, W. A., Simons, P. J., Glatz, J. F. C., Luiken, J. J. F. P., \& Larsen, T. S. (2015). Marine omega-3 fatty acids prevent myocardial insulin resistance and metabolic remodeling as induced experimentally by high insulin exposure. American Journal of Physiology-Cell Physiology, 308(4), C297-C307. https://doi.org/10.1152/ajpcell.00073.2014

Document status and date:

Published: 15/02/2015

DOI:

10.1152/ajpcell.00073.2014

Document Version:

Publisher's PDF, also known as Version of record

\section{Document license:}

Taverne

Please check the document version of this publication:

- A submitted manuscript is the version of the article upon submission and before peer-review. There can be important differences between the submitted version and the official published version of record.

People interested in the research are advised to contact the author for the final version of the publication, or visit the DOI to the publisher's website.

- The final author version and the galley proof are versions of the publication after peer review.

- The final published version features the final layout of the paper including the volume, issue and page numbers.

Link to publication

\footnotetext{
General rights rights.

- You may freely distribute the URL identifying the publication in the public portal. please follow below link for the End User Agreement:

www.umlib.nl/taverne-license

Take down policy

If you believe that this document breaches copyright please contact us at:

repository@maastrichtuniversity.nl

providing details and we will investigate your claim.
}

Copyright and moral rights for the publications made accessible in the public portal are retained by the authors and/or other copyright owners and it is a condition of accessing publications that users recognise and abide by the legal requirements associated with these

- Users may download and print one copy of any publication from the public portal for the purpose of private study or research.

- You may not further distribute the material or use it for any profit-making activity or commercial gain

If the publication is distributed under the terms of Article $25 \mathrm{fa}$ of the Dutch Copyright Act, indicated by the "Taverne" license above, 


\title{
Marine omega-3 fatty acids prevent myocardial insulin resistance and metabolic remodeling as induced experimentally by high insulin exposure
}

\author{
Veronika Franekova, ${ }^{1}$ Yeliz Angin, ${ }^{2}$ Nicole T. H. Hoebers, ${ }^{2}$ Will A. Coumans, ${ }^{2}$ Peter J. Simons, ${ }^{3}$ \\ Jan F. C. Glatz, ${ }^{2}$ Joost J. F. P. Luiken, ${ }^{2}$ and Terje S. Larsen ${ }^{1}$ \\ ${ }^{1}$ Cardiovascular Research Group, Department of Medical Biology, Health Sciences Faculty, UiT The Arctic University of \\ Norway, Troms $\phi$, Norway; ${ }^{2}$ Department of Molecular Genetics, Cardiovascular Research Institute Maastricht, Maastricht \\ University, Maastricht, the Netherlands; and ${ }^{3}$ Bioceros BV, Utrecht, the Netherlands
}

Submitted 10 March 2014; accepted in final form 19 November 2014

Franekova V, Angin Y, Hoebers NT, Coumans WA, Simons PJ, Glatz JF, Luiken JJ, Larsen TS. Marine omega-3 fatty acids prevent myocardial insulin resistance and metabolic remodeling as induced experimentally by high insulin exposure. Am J Physiol Cell Physiol 308: C297-C307, 2015. First published December 4, 2014; doi:10.1152/ajpcell.00073.2014.-Insulin resistance is an important risk factor for the development of several cardiac pathologies, thus advocating strategies for restoring insulin sensitivity of the heart in these conditions. Omega-3 polyunsaturated fatty acids ( $\omega-3$ PUFAs), mainly eicosapentaenoic acid (EPA, C20:5n-3) and docosahexaenoic acid (DHA, C22:6n-3), have been shown to improve insulin sensitivity in insulin-sensitive tissues, but their direct effect on insulin signaling and metabolic parameters in the myocardium has not been reported previously. The aim of this study was therefore to examine the ability of EPA and DHA to prevent insulin resistance in isolated rat cardiomyocytes. Primary rat cardiomyocytes were made insulin resistant by $48 \mathrm{~h}$ incubation in high insulin (HI) medium. Parallel incubations were supplemented by $200 \mu \mathrm{M}$ EPA or DHA. Addition of EPA or DHA to the medium prevented the induction of insulin resistance in cardiomyocytes by preserving the phosphorylation state of key proteins in the insulin signaling cascade and by preventing persistent relocation of fatty acid transporter CD36 to the sarcolemma. Only cardiomyocytes incubated in the presence of EPA, however, exhibited improvements in glucose and fatty acid uptake and cell shortening. We conclude that $\omega-3$ PUFAs protect metabolic and functional properties of cardiomyocytes subjected to insulin resistance-evoking conditions.

omega-3 PUFAs; cardiac metabolism; insulin resistance; CD36; adipose triglyceride lipase; sarcomere shortening

AN ELEVATED SUPPLY of lipids in obesity and type 2 diabetes leads to alterations of myocardial substrate metabolism, manifested insulin resistance with reduced glucose utilization, and increased long-chain fatty acid (LCFA) utilization $(2,3,39)$. Thus isolated cardiomyocytes from various diabetic/obese rodent models show impaired insulin signaling, including reduced activation of protein kinase $\mathrm{B}$ (Akt/PKB), reduced glucose transporter 4 (GLUT4) translocation from intracellular compartments to the sarcolemma, as well as impaired insulininduced glucose uptake $(10,35,37)$. Glucose and LCFA are the major substrates for the heart, and GLUT4 and CD36 the major substrate transporters, which are regulated by reversible insulin-induced translocation (48). Notably, increased LCFA supply to cardiomyocytes will evoke persistent relocation of

Address for reprint requests and other correspondence: V. Franekova, Cardiovascular Research Group, Dept. of Medical Biology, Health Sciences Faculty, UiT The Arctic Univ. of Norway, 9037 Troms $\varnothing$, Norway (e-mail: veronika.franekova@uit.no).
CD36 from intracellular stores to the sarcolemma, followed by chronically elevated LCFA uptake and lipid accumulation, eventually resulting in insulin resistance $(5,36)$. Additionally, sustained hyperinsulinemia itself has also been shown to chronically stimulate CD36 translocation in cardiomyocytes and, consequently, lead to insulin resistance in a very similar manner to cardiomyocytes exposed to LCFA oversupply, as reported previously (5). We also found that insulin-resistant cardiomyocytes exhibit contractile dysfunction (reduced cell shortening) (5).

Numerous in vivo studies in rodent models of obesity and diabetes have clearly shown that diets enriched in EPA and/or DHA improve whole body insulin resistance $(15,22,42,45)$. However, findings on the effect of $\omega-3$ PUFAs on human insulin resistance are controversial, since some studies reported no clear improvements, while others showed positive effects on insulin sensitivity $(4,13,27,31,44,47,51)$. The explanation for these controversial findings remains unclear but may be attributable to differences in health status, medication, diet, and compliance among the subjects, as well as differences in duration and dose of $\omega-3$ PUFAs administration. Regardless of the inconsistencies, a number of in vivo and in vitro studies show that intake of $\omega-3$ PUFAs may lead to reduction of insulin resistance due to their effect on expression and activity of glucose metabolizing enzymes, decreased expression of lipogenesis enzymes, increased fatty acid oxidation, or the ability to inhibit inflammation $(13,21,32)$. However, despite these known benefits, the direct effect of EPA and DHA on insulin signaling as well as on metabolic and functional parameters of the heart has not been assessed yet.

To test the putative preventive effect of EPA and DHA on myocardial insulin resistance, primary rat cardiomyocytes were made insulin resistant by long-term exposure to a medium containing high concentrations of insulin, as previously described $(5,6)$. Cells cultured under these conditions were coincubated with EPA and DHA complexed to albumin. Insulin sensitivity was evaluated by examining the response to acute insulin exposure on glucose and LCFA uptake, as well as phosphorylation of selected proteins in the insulin signaling cascade. In addition, the effect of EPA and DHA on the presence of fatty acid transport protein CD36 in the sarcolemma was examined by confocal microscopy. Of interest, several studies in rat and mouse models of pressure overloadinduced heart failure have reported that intake of EPA and DHA prevents left ventricular remodeling and contractile dysfunction $(8,12,34)$. Therefore, we also examined the effect of EPA and DHA on myocardial cell shortening. 


\section{MATERIALS AND METHODS}

Medium M199 and penicillin/streptomycin were purchased from Invitrogen (Carlsbad, CA). Phloretin, laminin, creatine monohydrate, carnitine hydrochloride, taurine, insulin, palmitic acid, EPA, and DHA were purchased from Sigma Aldrich (St. Louis, MO). Collagenase type II was from Worthington (Freehold, NJ). BSA (essentially fatty acid free, fraction V) was derived from MP Biomedicals (Irvine, $\mathrm{CA}$ ) or from Sigma Aldrich (St. Louis. MO). $\left[1-{ }^{3} \mathrm{H}\right]$ deoxyglucose and $\left[1-{ }^{14} \mathrm{C}\right]$ palmitate were obtained from GE Healthcare (Piscataway, NJ). The anti-CD36 monoclonal antibody (clone CRF D2717) was from BD Biosciences (San Jose, CA) and was provided by Bioceros BV (Utrecht, the Netherlands).

Experimental animals. Male Lewis rats were purchased from Charles River Laboratories (Boston, MA) and were used for isolation of cardiomyocytes. All animals were fed ad libitum. All procedures were approved by the Experimental Animal Committee of Maastricht University, Maastricht, the Netherlands.

Cardiomyocytes isolation and culturing. Isolation of rat adult cardiomyocytes (Lewis rats, 200-250 g, 2-3 mo of age) was performed by using a Langendorff perfusion system according to the procedure described previously (29) with the only difference being sterile conditions that were taken into account to enable subsequent culturing. A modified Krebs-Ringer buffer (MKR) containing $1.17 \mathrm{M}$ $\mathrm{NaCl}, 26 \mathrm{mM} \mathrm{KCl}, 12 \mathrm{mM} \mathrm{KH} \mathrm{PO}_{4}, 12 \mathrm{mM} \mathrm{MgSO} 4 \cdot 7 \mathrm{H}_{2} \mathrm{O}, 100 \mathrm{mM}$ $\mathrm{NaHCO}_{3}$, and $100 \mathrm{mM}$ HEPES with $\mathrm{pH}$ adjusted to 7.55 was equilibrated with $95 \% \mathrm{O}_{2}-5 \% \mathrm{CO}_{2}$ gas phase and used for isolation and experiments with cardiomyocytes.

After isolation of cardiomyocytes, 100,000 cells/ml were seeded in MKR buffer supplemented with $0.45 \%$ (wt/vol) BSA on laminincoated six-well plates $\left(9.6 \mathrm{~cm}^{2}\right)$. For sarcomere shortening and the surface CD36 measurements cells were seeded on 35-mm-high dishes with an elastic surface (Ibidi GmBH, Munich, Germany). After 90 min adhesion, the medium was replaced with control medium (medium M199 supplemented with $5 \mathrm{mM}$ creatine monohydrate, $3.2 \mathrm{mM}$ carnitine hydrochloride, $3.1 \mathrm{mM}$ taurine, 100 units $/ \mathrm{ml}$ penicillin, 10 $\mathrm{mg} / \mathrm{ml}$ streptomycin, and $20 \mu \mathrm{M}$ palmitate), HI medium (control medium supplemented with $100 \mathrm{nM}$ insulin), or fatty acid medium (HI medium supplemented with $200 \mu \mathrm{M}$ EPA or DHA). For cardiomyocytes cotreated with anti-CD36 (clone CRF D2717) an antibody concentration $0.415 \mu \mathrm{g} / \mathrm{ml}$ was used. Fatty acids were bound to BSA (essentially fatty acid free) in a ratio $4: 1$. BSA was used as fatty acid free control added to the control medium to avoid interference from vehicle. Cardiomyocytes were kept in $5 \% \mathrm{CO}_{2}$ at $37^{\circ} \mathrm{C}$ for $48 \mathrm{~h}$. Medium was refreshed after $24 \mathrm{~h}$ of seeding. Following $48 \mathrm{~h}$ of culturing, cells were washed and allowed to recover for $30 \mathrm{~min}$ in MKR buffer supplemented with $0.45 \%$ (wt/vol) BSA and $1 \mathrm{mM}$ $\mathrm{CaCl}_{2}$ prior to start of $25 \mathrm{~min}$ incubation with or without insulin $(100 \mathrm{nM})$.

Measurement of substrate uptake. The uptake of $\left[1-{ }^{3} \mathrm{H}\right]$ deoxyglucose and of $\left[1-{ }^{14} \mathrm{C}\right]$ palmitate (in complex with BSA) was measured in cultured cardiomyocytes. During 25 min treatment with/without insulin $(100 \mathrm{nM})$, trace amounts of $\left[1-{ }^{3} \mathrm{H}\right]$ deoxyglucose and [1${ }^{14} \mathrm{C}$ ]palmitate were added to the medium for the last $10 \mathrm{~min}$ of incubation. Thereafter, cells were washed twice on ice with MKR buffer supplemented with $1 \mathrm{mM} \mathrm{CaCl} \mathrm{Ca}_{2}$ and $0.2 \mathrm{mM}$ phloretin, and then lysed in sample buffer [40\% (vol/vol) glycerol, $0.25 \mathrm{M}$ Tris, and 1 M DTT] followed by assessment of radioactivity in scintillation fluid (Opti-Fluor; PerkinElmer, Waltham, MA).

Detection of phosphorylation of enzymes within the insulin signaling network. Following a 25 min treatment with/without insulin (100 $\mathrm{nM}$ ) cardiomyocytes were lysed in sample buffer and used for protein detection. Approximately $20 \mu \mathrm{g}$ per sample was used for SDS-PAGE followed by Western blotting.

Primary antibodies specific to Akt, phospho-Ser473-Akt, phosphoThr172-AMPK $\alpha$, phospho-Ser9-glycogen synthase kinase $3 \beta$ (GSK3 $\beta$ ), mammalian target of rapamycin (mTOR), phospho-
Ser2448-mTOR, p70 S6K, phospho-Thr389-p70 S6K, and adipose triglyceride lipase (ATGL) purchased from Cell Signaling Technology (Denver, CO), phospho-Ser79-ACC and phospho-Thr642-AS160 (AS160-Akt substrate of $160 \mathrm{kDa}$ ) from Upstate Biotechnology (Millipore), GLUT4 and GLUT1 from Abcam (Cambridge, MA), and Caveolin 3 from BD Transduction Laboratories (Franklin Lakes, NJ) were used. The anti-CD36 MO25 antibody was a gift from N. N. Tandon (Thrombosis Research Laboratory, Otsuka Maryland Medicinal Laboratories Rockville, MD) and was used only for Western blotting. Western blot images were analyzed with a molecular imager (ChemiDoc XRS, Bio-Rad Laboratories) or Kodak imaging system (Kodak, Scientific Imaging Systems, Rochester, NY) and quantified with Quantity One (Bio-Rad Laboratories) or Kodak 1D Image Analysis Software (Kodak).

Quantitative real-time PCR. Primary rat cardiomyocytes cultured under different conditions were harvested after $48 \mathrm{~h}$ and used as the source for mRNA extraction using the Perfect Pure RNA Cultured Cell kit (5Prime, Norway) following the manufacturer's protocol. Rat RNA isolated from individual samples was converted to cDNA using High-Capacity cDNA Reverse Transcription Kit (Applied Biosystems) following the manufacturer's protocol. Real-time quantitative PCR was performed using ABI PRISM 7900 HT Fast real-time thermal cycler (Applied Biosystems). Measurement of mRNA expression levels of ATGL and Acyl-CoA:diacylglycerol acyltransferase-1 (DGAT-1) was determined by SYBR Green master mix (Applied Biosystems) using the following rat primer pairs obtained from Sigma (Norway): ATGL forward (ggcctactgaaccaacccaa), reverse (agccactccaacaaacgcat); and DGAT-1 forward (gttcagctcagacagcggttt), reverse (catcaccacgcaccaattca). GAPDH served as the housekeeping reference gene for measuring the levels of the individual mRNA.

Sarcolemmal presence of CD36. Following $48 \mathrm{~h}$ of culturing, cells were washed twice with control medium, treated with primary antibody against $\mathrm{CD} 36$ (BD Biosciences) for $10 \mathrm{~min}$ at $37^{\circ} \mathrm{C}$ followed by incubation with FITC-labeled rabbit-anti-mouse IgA secondary antibodies (Rockland Immunochemicals, Gilbertsville, PA). The viable cardiomyocytes were imaged using the Leica SP5 imaging platform in confocal mode (Leica Microsystems) with the emission filters optimized for FITC detection. Images were processed with ImageJ (NIH).

Measurement of sarcomere shortening. Following $48 \mathrm{~h}$ of culturing, cells were washed twice with control medium and subsequently analyzed for contractile function as previously described (18). Before the start of the measurements, cells were electrically prestimulated for $5 \mathrm{~min}$ with $1 \mathrm{~Hz}$ to reach a steady-state level for sarcomere shortening. Then cells were paced with bipolar pulses of $5 \mathrm{~ms}$ duration at $1 \mathrm{~Hz}$. Under each experimental condition, data files were recorded of 10 consecutive beats for at least eight different cells. Sarcomere shortening was measured with IonOptix (Dublin, Ireland) and calculated using IonWizard (IonOptix).

Statistical analysis and data presentation. All data are presented as means \pm SE. Statistical analyses were performed by one-way ANOVA followed by Tukey post test using GraphPad Prism Program (GraphPad Software, San Diego, CA). $P<0.05$ was considered as significant.

\section{RESULTS}

Effect of EPA and DHA on glucose uptake. Insulin resistance was induced in primary rat cardiomyocytes during $48 \mathrm{~h}$ exposure to a medium containing high concentration $(100 \mathrm{nM})$ of insulin (HI medium). In addition, cardiomyocytes incubated in HI medium were coincubated with $200 \mu \mathrm{M}$ EPA or DHA. Cardiomyocyte insulin sensitivity was assessed by insulinstimulated glucose uptake.

Cardiomyocytes cultured for $48 \mathrm{~h}$ in control medium (medium without $\mathrm{HI}$ ) responded to acute $(25 \mathrm{~min})$ stimulation with insulin $(100 \mathrm{nM})$ by a 3.4-fold increase in glucose uptake, 
while glucose uptake was hardly increased by acute insulin stimulation in cardiomyocytes cultured in HI medium (insulinresistant cells). Culturing of cardiomyocytes in $\mathrm{HI}$ medium in the presence of EPA elevated insulin-stimulated glucose uptake and thus prevented the loss of insulin sensitivity (Fig. 1A). Interestingly, basal glucose uptake was also significantly elevated in cardiomyocytes upon EPA exposure during $48 \mathrm{~h}$ of culturing in $\mathrm{HI}$ medium. Thus there was no difference in insulin-induced increment in glucose uptake between control and EPA-treated cardiomyocytes (Fig. 1A).

The effect of DHA on glucose uptake was tested in parallel experiments, and like EPA, DHA also caused an increase in basal glucose uptake in cardiomyocytes subjected to insulin resistance-evoking conditions. On the other hand, DHA treatment did not prevent the loss of insulin-stimulated glucose uptake in cardiomyocytes cultured in $\mathrm{HI}$ medium (Fig. 1A).

Figure $1 B$ shows that the observed improvements in glucose uptake upon exposing cardiomyocytes to EPA or DHA were not associated with alterations in the total level of the glucose transporter GLUT1 or GLUT4.

Effect of EPA and DHA on insulin signaling pathway. A commonly used read-out of insulin resistance is decreased phosphorylation of enzymes in the canonical insulin signaling pathway. Insulin resistance upon $48 \mathrm{~h}$ culturing in $\mathrm{HI}$ medium was confirmed in cardiomyocytes by markedly lower phosphorylation of Akt/PKB (phospho-Ser473) and two of its downstream substrates, GSK3 $\beta$ (phospho-Ser9) and AS160 (phospho-Thr642-AS160), in response to acute (25 min) exposure to insulin (100 nM), compared with that of control cells (Fig. 2, $A$ and $C-E$ ). Insulin resistance was also observed at the level of mTOR, given the decrease in phosphorylation of mTOR (phospho-Ser2448) and its direct target p70 S6K (phospho-Thr389) (Fig. 2, $B, F$, and $G$ ). Addition of EPA or DHA to the culture medium during the $48 \mathrm{~h}$ incubation with $\mathrm{HI}$ almost completely prevented the loss of insulin sensitivity at the level of Akt/PKB, since insulin-induced phosphorylation of Akt/ PKB, GSK3 $\beta$, and AS160 was largely retained (Fig. 2, $A$ and $C-E$ ). However, insulin sensitivity was not preserved by EPA or DHA at the level of mTOR and p70 S6K phosphorylation (Fig. 2, $B, F$, and $G$ ). We also observed that exposure of $\mathrm{HI}$ medium-cultured cardiomyocytes to $\omega-3$ PUFAs (especially EPA) caused a slight increase in basal phosphorylation of proteins involved in insulin signaling (Fig. 2, A-G). These changes in insulin signaling were not due to different loading or changes in total expression of Akt/PKB, mTOR, or p70 S6K (data not shown).

Effect of EPA and DHA on AMPK signaling. It is also disputed whether activation of AMP-activated protein kinase (AMPK) is involved in the beneficial effects of $\omega-3$ PUFAs. Namely, mice treated with diet containing these fatty acids did not show any changes in the activity of myocardial AMPK (11), whereas $\omega$-3 PUFAs have been shown to enhance AMPK activity in other tissues $(16,23,26,46)$. Hence, we assessed the phosphorylation level of AMPK and its downstream target, acetyl-CoA carboxylase (ACC). Culturing of cardiomyocytes in HI medium in the presence of EPA or DHA had, however, no significant effect on AMPK or ACC phosphorylation (Fig. 3). Hence, AMPK seems not to be involved in these beneficial actions of EPA and DHA.

Effect of EPA and DHA on fatty acid uptake, sarcolemmal presence of CD36, and fatty acid-metabolic enzymes. Cardiomyocytes cultured for $48 \mathrm{~h}$ in control medium responded to acute stimulation with insulin by a 1.4-fold increase in palmitate uptake. This response was lost in cardiomyocytes cultured under $\mathrm{HI}$ conditions, while inclusion of EPA (but not DHA) in the $\mathrm{HI}$ medium prevented the loss of insulin sensitivity (Fig. 4A). Furthermore, both EPA and DHA treatment caused a marked ( $>2$-fold) stimulation of basal palmitate uptake in cardiomyocytes cultured under $\mathrm{HI}$ conditions. The changes in palmitate uptake were not associated with changes in the total
A

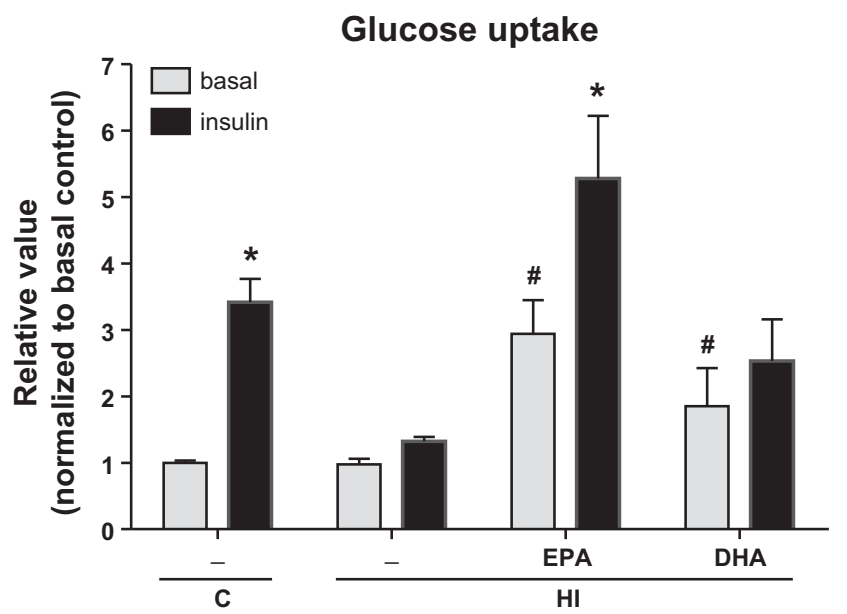

B

\begin{tabular}{|c|c|c|c|c|c|c|c|c|}
\hline \multirow{2}{*}{} & \multicolumn{2}{|c|}{ C } & \multicolumn{4}{c|}{ HI } \\
\cline { 2 - 9 } & \multicolumn{2}{|c|}{-} & \multicolumn{2}{|c|}{-} & \multicolumn{2}{c|}{ EPA } & \multicolumn{2}{c|}{ DHA } \\
\hline & B & Ins & B & Ins & B & Ins & B & Ins \\
\hline GLUT1 & & & & & & & & \\
\hline GLUT4 & & & & & & & & \\
\hline Cav3 & & & & & & & & \\
$-45 \mathrm{kDa}$ \\
$-18 \mathrm{kDa}$
\end{tabular}

Fig. 1. Effect of omega-3 polyunsaturated fatty acids ( $\omega$-3 PUFAs) on glucose uptake and total expression level of GLUT1 and GLUT4. Cardiomyocytes were preincubated for $48 \mathrm{~h}$ in control medium (C) or in medium supplied with $100 \mathrm{nM}$ insulin (HI) in the absence or presence of $200 \mu \mathrm{M}$ eicosapentaenoic acid (EPA) or docosahexaenoic acid (DHA). Thereafter, cells were washed and allowed to recover for 30 min prior to short-term (25 min) incubation with or without insulin $(100 \mathrm{nM})$. For measurement of glucose uptake $\left[{ }^{3} \mathrm{H}\right]$ deoxyglucose was added to medium for the last $10 \mathrm{~min}$ of incubation. A: glucose uptake data obtained from cardiomyocytes cultured in control or HI medium in the absence or presence of $\omega-3$ PUFAs during basal and insulin-stimulated conditions. Results are represented as mean values $\pm \mathrm{SE}(n=11$ for treatment with EPA, $n=4$ for treatment with DHA). $* P<0.05$ vs. corresponding basal value; $\# P<0.05$ vs. basal value in the absence of $\omega-3$ PUFAs. $B$ : representative Western blot analyses $(n=4-6)$ of total GLUT1 and GLUT4 in cardiomyocytes cultured in control or HI medium in the absence or presence of $\omega$-3 PUFAs during basal (B) and insulin-stimulated conditions (Ins). Caveolin 3 (Cav3) was used as loading control. 
A

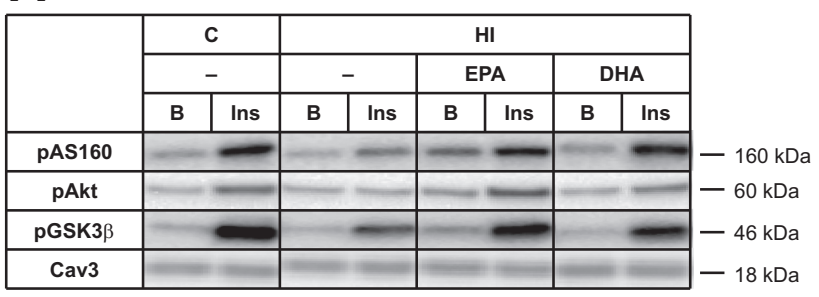

C

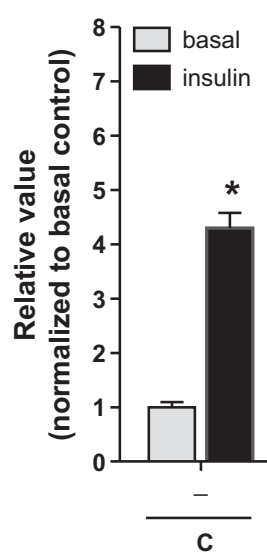

$\mathbf{E}$
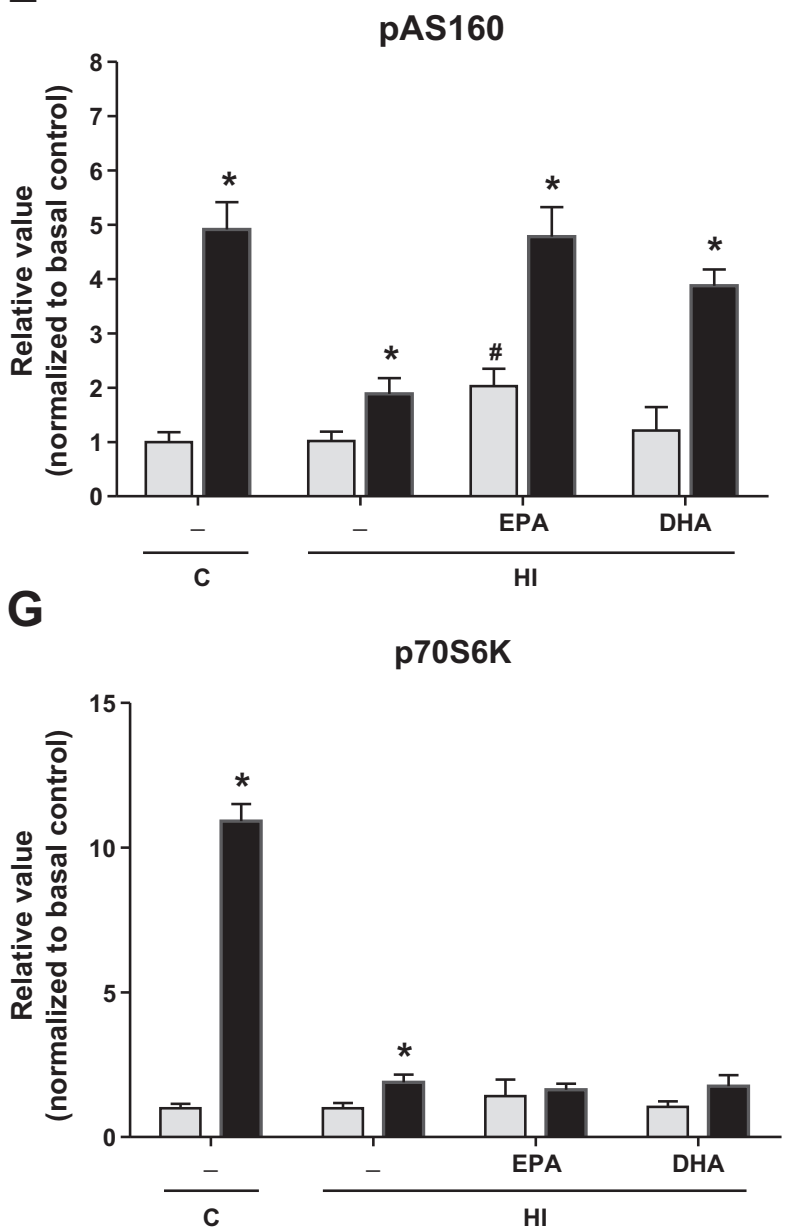

B

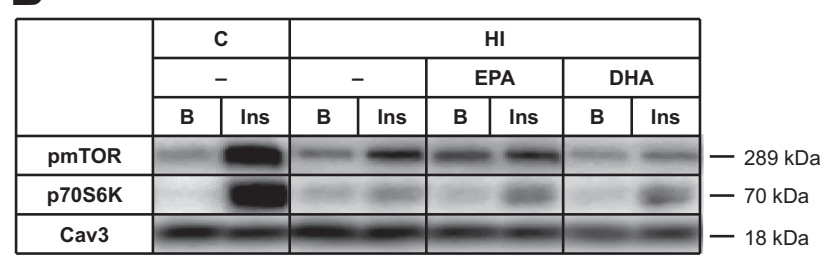

D

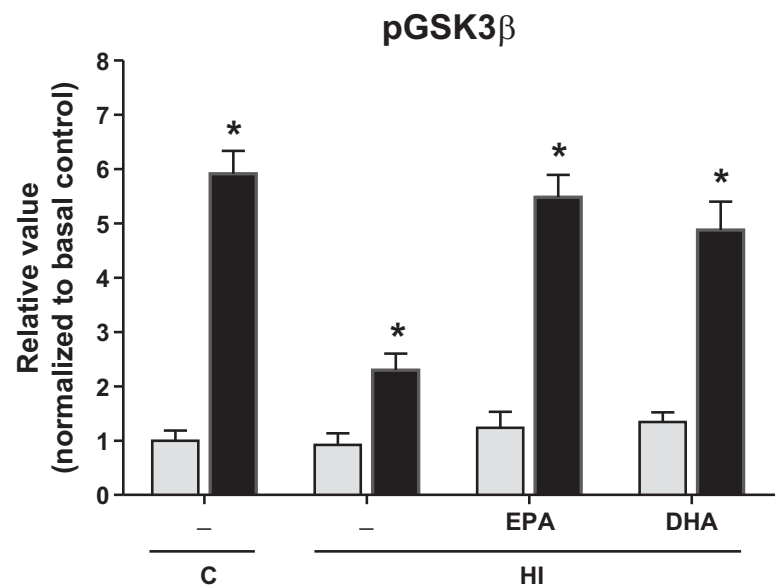

$\mathbf{F}$

pmTOR

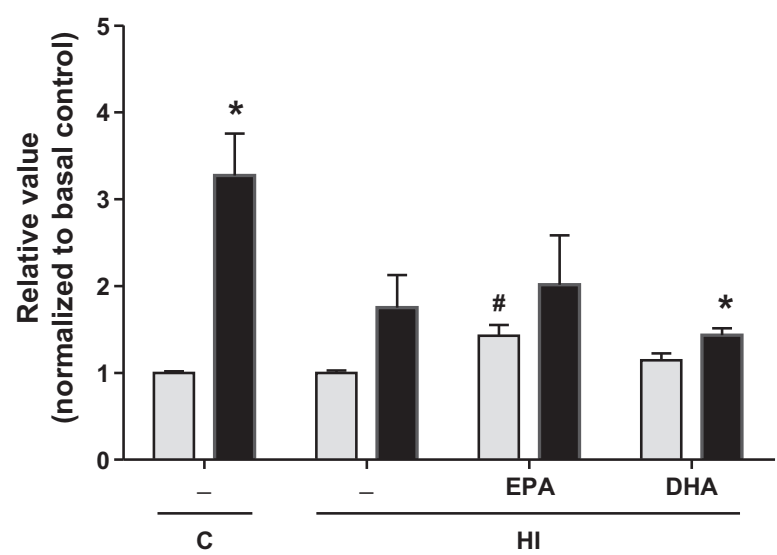




\begin{tabular}{|c|c|c|c|c|c|c|c|c|}
\hline \multirow{2}{*}{} & \multicolumn{2}{|c|}{ C } & \multicolumn{5}{c|}{ HI } \\
\cline { 2 - 8 } & \multicolumn{2}{|c|}{-} & \multicolumn{2}{|c|}{-} & \multicolumn{2}{c|}{ EPA } & \multicolumn{2}{c|}{ DHA } \\
\hline & B & Ins & B & Ins & B & Ins & B & Ins \\
\hline pACC & & & & & & & & \\
\hline pAMPK & & & & & & & \\
\hline Cav3 & & & & & & & & \\
$-62 \mathrm{kDa}$ & $-18 \mathrm{kDa}$ \\
\hline
\end{tabular}

Fig. 3. Effect of $\omega-3$ PUFAs on AMPK signaling. Cardiomyocytes were pretreated and stimulated with insulin as described in the legend of Fig. 1. Representative Western blot analyses $(n=6)$ of phospho-Thr172-AMPK $\alpha$ AMPK (pAMPK) and phospho-Ser79-ACC (pACC) in cardiomyocytes cultured in control (C) or high insulin (HI) medium in the absence or presence of $\omega$-3 PUFAs during basal (B) and insulin-stimulated conditions (Ins). Caveolin 3 (Cav3) was used as loading control.

cellular content of the fatty acid transporter CD36 (Fig. 4B). We also examined the sarcolemmal abundance of CD36 by using immunofluorescence microscopy (Fig. 4, $C$ and D). Cardiomyocytes cultured in HI medium exhibited a markedly elevated cell surface CD36 content. Persistent CD36 relocation was reversed in incubations with EPA or DHA.

We have shown earlier that the fatty acid transport function of CD36 can be blocked by specific anti-CD36 antibody (5). In line with this result, we found that coincubation of EPA with anti-CD36 antibody abolished both basal and insulin-stimulated palmitate uptake in cardiomyocytes, which might suggest that EPA exerts its insulin sensitizing action after having been taken up across the cell membrane through CD36 (Fig. 4A).

To obtain information about the effects of EPA and DHA on the metabolic fate of fatty acids in cardiomyocytes cultured under HI conditions, especially in relation to incorporation into myocellular lipid pools, we studied the effects of these treatments on expression of acyl-CoA:diacylglycerol acyltransferase-1 (DGAT-1), a key enzyme involved in triacylglycerol synthesis, and of ATGL, a key enzyme in triacylglycerol breakdown. mRNA expression of DGAT-1 was not different in any conditions (Fig. 5A). mRNA expression of ATGL was not different between control cells and cells cultured under $\mathrm{HI}$ conditions, but increased upon treatment with EPA (Fig. 5B). This stimulatory action of EPA on ATGL expression was confirmed at the protein level (Fig. 5, $C$ and $D$ ). The presence of DHA had, however, no significant effect on ATGL expression (Fig. 5, B-D).

Effect of EPA and DHA on cardiomyocyte contractility (shortening). It has been previously shown that long-term exposure of primary rat cardiomyocytes to $\mathrm{HI}$ is associated with impaired peak sarcomere shortening (5), which was confirmed in the present study (Fig. 6). Here we investigated the effect of EPA and DHA on sarcomere shortening of cardiomyocytes cultured in HI medium for $48 \mathrm{~h}$. EPA improved peak sarcomere shortening by 1.6-fold (Fig. 6). DHA also improved sarcomere shortening (1.5-fold); however, this effect did not reach statistical significance $(P>0.05$; Fig. 6). Hence, EPA, and perhaps DHA, has a beneficial effect on contractile function of cardiomyocytes cultured under such insulin resistanceevoking conditions.

Effect of EPA in insulin-sensitive cardiomyocytes. For comparative reasons we assessed whether $\omega$-3 PUFAs affected substrate uptake in normal cardiomyocytes (cultured without $\mathrm{HI}$ ), using only EPA since it showed a greater scale of beneficial effects than DHA under HI conditions.

Like HI medium-cultured cardiomyocytes, control cells also showed elevated basal glucose uptake and a clear response to insulin following exposure to EPA (Fig. 7A). Basal fatty acid uptake was also increased in normal cardiomyocytes treated with EPA; however, these cells did not respond to acute insulin treatment (Fig. 7B). The changes in glucose and palmitate uptake were not associated with changes in the total cellular content of the glucose transporter GLUT1, GLUT4, or fatty acid transporter CD36 (data not shown).

Finally, just as in insulin-resistant cardiomyocytes, EPA treatment also decreased the plasma membrane level of CD36 (Fig. 8, $A$ and $B$ ), increased ATGL expression (Fig. 8, $C-E$ ), did not alter DGAT-1 expression (data not shown), and improved the contractility in normal cardiomyocytes compared with control cells (Fig. 8F).

\section{DISCUSSION}

Dysregulation of cardiac substrate metabolism in conditions of insulin resistance (obesity and/or type 2 diabetes) eventually leads to functional deterioration of the heart. In the present study we investigated the effect of $\omega-3$ PUFAs on insulin signaling and substrate uptake in cardiomyocytes cultured under insulin resistance-evoking conditions generated by a high concentration of insulin. The main finding was that inclusion of $\omega-3$ PUFAs in the HI medium counteracted the development of insulin resistance. Apparently, the potential of EPA to prevent insulin resistance exceeded that of DHA.

Before elaborating on the potential beneficial effects of $\omega-3$ PUFAs against the development of insulin resistance, it is worthwhile to mention that EPA has already clear metabolic and functional actions in normal insulin-sensitive cardiomyocytes. Specifically, we found that basal glucose and palmitate uptake were increased after treatment with this fatty acid. Aas et al. (1) also observed an increase in basal glucose and fatty acid uptake after treatment with EPA in human skeletal muscle cells. This observation could probably be explained in terms of a general anabolic effect of $\omega-3$ PUFAs, in line with results reported by Smith et al. (43) showing increased muscle protein concentration in response to dietary intake of $\omega-3$ PUFAs. However, in light of the observation that EPA or DHA did not increase p70 S6K phosphorylation, the activity of the anabolic master regulator mTOR appears not to be altered by these $\omega-3$

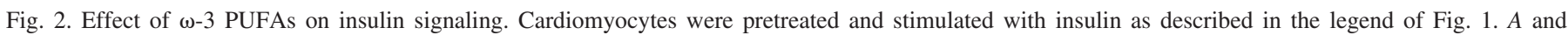

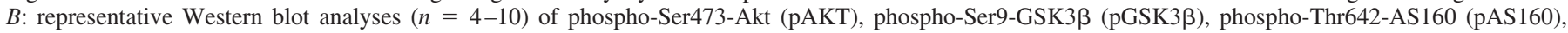

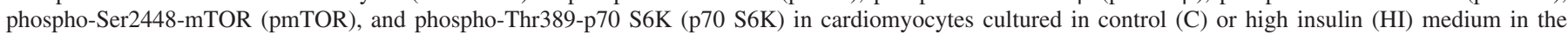

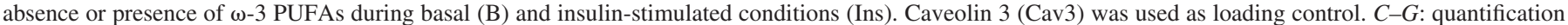

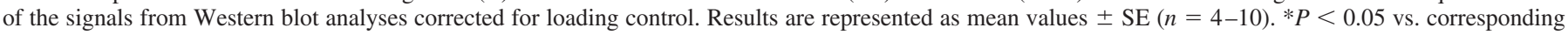
basal value; $\# P<0.05$ vs. basal value in the absence of $\omega-3$ PUFAs. 
$\mathbf{A}$

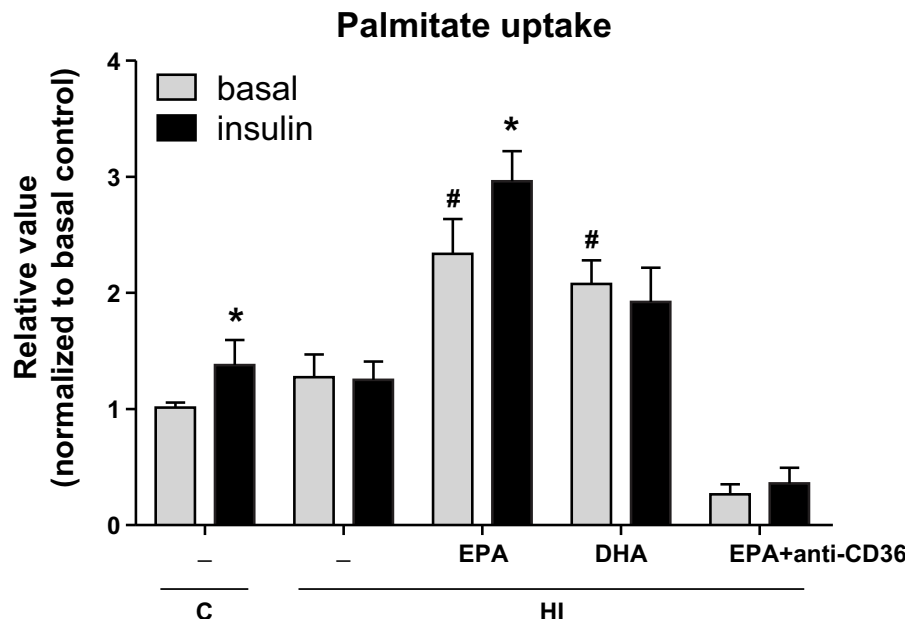

C

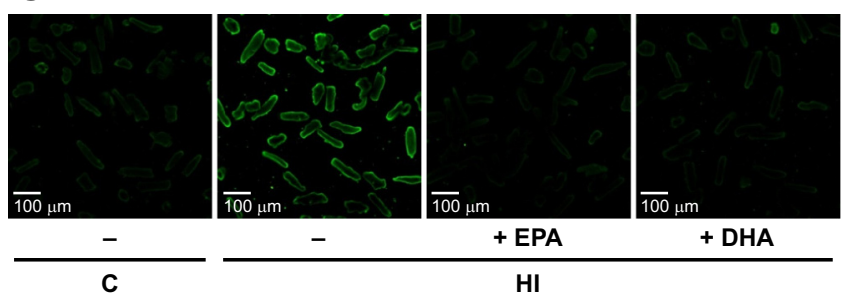

B

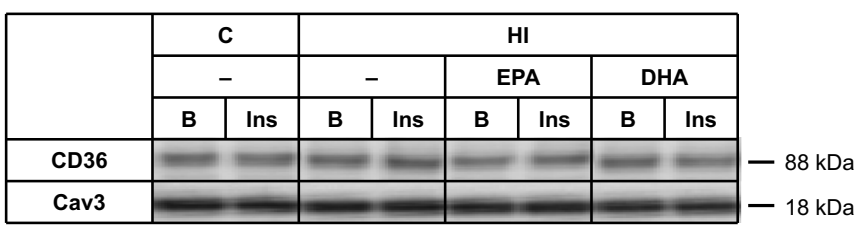

D

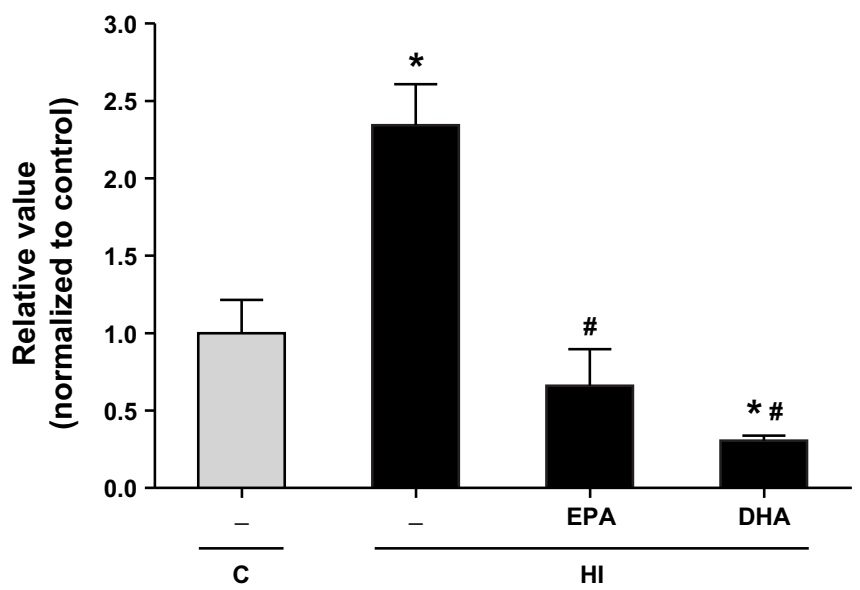

Fig. 4. Effect of $\omega-3$ PUFAs on palmitate uptake, total expression level, and cell-surface content of CD36. Cardiomyocytes were pretreated and stimulated with insulin as described in the legend of Fig. 1. For measurement of palmitate uptake $\left[{ }^{14} \mathrm{C}\right]$ palmitate was added to medium for last $10 \mathrm{~min}$ of incubation. $A$ : palmitate uptake data obtained from cardiomyocytes cultured in control (C) or high insulin (HI) medium in the absence or presence of $\omega$-3 PUFAs during basal and insulin-stimulated conditions. Also shown are data from cardiomyocytes cultured in the presence of EPA coincubated with anti-CD36 antibody. Results are represented as mean values $\pm \mathrm{SE}(n=11$ for treatment with EPA, $n=4$ for treatment with DHA). $* P<0.05$ vs. corresponding basal value; $\# P<0.05$ vs. basal value in the absence of $\omega$-3 PUFAs. $B$ : representative Western blot analyses $(n=4)$ of total CD36 in cardiomyocytes cultured in control or HI medium in the absence or presence of $\omega-3$ PUFAs during basal (B) and insulin-stimulated conditions (Ins). Caveolin 3 (Cav3) was used as loading control. $C$ : representative confocal images $(n=3)$ showing surface staining of CD36 in cardiomyocytes cultured in control or HI medium in the absence or presence of $200 \mu \mathrm{M}$ EPA or DHA. $D$ : quantification of the signals from confocal images. Results are represented as mean values \pm SE. $* P<0.05$ vs. control value; $\# P<0.05$ vs. HI value in the absence of $\omega-3$ PUFAs.

PUFAs. Hence, the $\omega$-3 PUFAs-mediated increase in substrate uptake remains unresolved.

The presently observed ability of $\omega-3$ PUFAs to antagonize the development of insulin resistance in cardiomyocytes at the level of the Akt/PKB pathway or glucose uptake is in line with previous results in other cellular models. Thus improved insulin-stimulated glucose uptake was observed after the treatment with EPA or DHA in skeletal muscle cells, as well as in adipocytes cocultured with macrophages $(1,33)$.

Insulin-stimulated glucose uptake in cardiac myocytes is mediated by translocation of the glucose transporter GLUT4 from intracellular compartments to the plasma membrane (14). In accordance with previous studies $(1,25)$ we found that the preserved insulin sensitivity in cardiomyocytes coincubated with EPA or DHA during HI conditions was not associated with changes in the total cellular content of GLUT4. Because of experimental limitations, we were not able to measure GLUT4 translocation (surface GLUT4). However, several reports have shown that insulin-stimulated glucose transport in the heart appears to be primarily mediated by the Akt/PKB signaling pathway, and that defects in GLUT4 translocation are associated with alterations in this pathway $(7,9,20)$. Furthermore, the Rab GTPase-activating protein AS160 is a substrate for Akt/PKB and serves as a link between insulin activation of $\mathrm{Akt} / \mathrm{PKB}$ and the subsequent translocation of GLUT4 to the cell surface (41). As expected, induction of insulin resistance in cardiomyocytes (in response to long-term $\mathrm{HI}$ exposure) was associated with reduced phosphorylation of both Akt/PKB and AS160.

One should bear in mind, however, that Akt/PKB is not the only kinase responsible for phosphorylation of AS160. For example, AMPK, independently of insulin, is also able to 
A
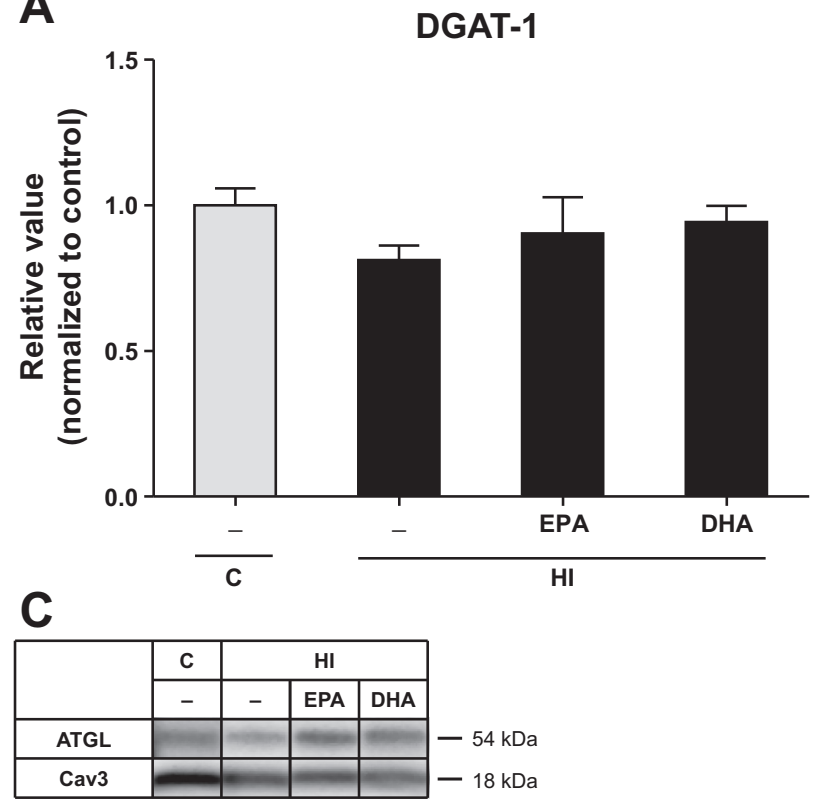

B

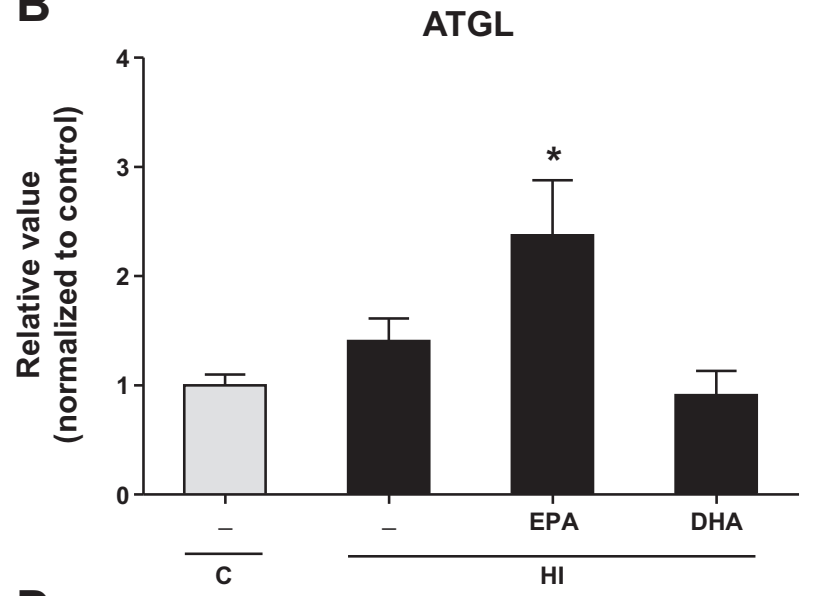

D

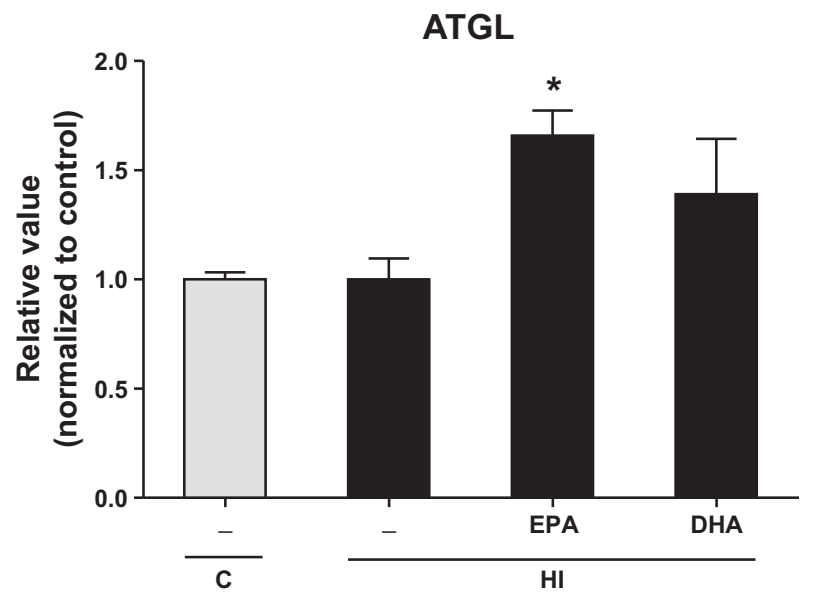

Fig. 5. Effect of $\omega-3$ PUFAs on fatty acid-metabolic enzymes. Cardiomyocytes were pretreated as described in the legend of Fig. 1 . $A$ and $B$ : mRNA expression of acyl-CoA:diacylglycerol acyltransferase-1 (DGAT-1) and adipose triglyceride lipase (ATGL) in cardiomyocytes cultured in control (C) or high insulin (HI) medium in the absence or presence of $\omega$-3 PUFAs. Levels of DGAT-1 and ATGL were quantified relative to the housekeeping control gene GAPDH. $C$ : representative Western blot analyses $(n=4)$ of ATGL in cardiomyocytes cultured in control (C) or high insulin (HI) medium in the absence or presence of $\omega-3$ PUFAs. Caveolin 3 (Cav3) was used as loading control. $D$ : quantification of the signals from Western blot analyses corrected for loading control. Results are represented as mean values $\pm \operatorname{SE}(n=4) .{ }^{*} P<0.05$ vs. basal value in the absence of $\omega-3$ PUFAs.

phosphorylate AS160 (24) and stimulate glucose uptake in the heart $(6,40)$. Nonetheless, our present results indicate that EPA or DHA do not activate AMPK. However, still other mechanisms could be responsible for preservation of insulin signaling and insulin-stimulated glucose uptake by $\omega$-3 PUFAs (especially EPA) during culturing of cardiomyocytes under insulin resistance-inducing conditions.

Interestingly, while EPA treatment preserved both insulininduced Akt/PKB phosphorylation and insulin-stimulated glucose uptake, DHA improved only Akt/PKB phosphorylation. This should not be entirely surprising, however, as some studies have already shown that the PKB/Akt pathway and glucose uptake downstream of insulin might be disconnected $(17,50,52)$. The subcellular trafficking machinery dedicated to GLUT4 translocation includes, however, activation of proteins in addition to Akt/PKB (e.g., SNARE proteins, motor proteins, coat proteins, etc.), and the apparent discrepancy between EPA and DHA on GLUT4 translocation could therefore be explained by a lower efficacy of DHA to interact with these other proteins.

In contrast to the preservation of the insulin effect on phosphorylation of Akt/PKB in cardiomyocytes cultured under HI conditions, insulin signaling at the level of mTOR appeared not to be preserved. It should be remembered that activation of mTOR is a very complex process involving $\mathrm{Akt} / \mathrm{PKB}$, but also numerous other kinases and regulatory proteins, and it is under control of several feedback loops as well (49). Thus it seems that EPA and DHA are able to selectively protect $\mathrm{Akt} / \mathrm{PKB}$, but not other proteins needed for mTOR activation.

Redistribution of CD36 from intracellular stores to the plasma membrane and lipid accumulation are hallmark changes occurring in the heart during diet-induced obesity and insulin resistance $(5,28)$. Thus cardiomyocytes which were made insulin resistant by HI displayed elevated sarcolemmal CD36 content. EPA and DHA increased palmitate uptake, but, surprisingly, this response was accompanied neither by changes in the total expression of CD36 nor by translocation of CD36 to the plasma membrane. On the contrary, inclusion of EPA or DHA significantly prevented the robust translocation of CD36 to the sarcolemma, which was otherwise seen in the insulin-resistant cardiomyocytes. At a first glance, this observation seems paradoxical, but on the other hand it shows that exposure to EPA or DHA prevented one of the main processes 


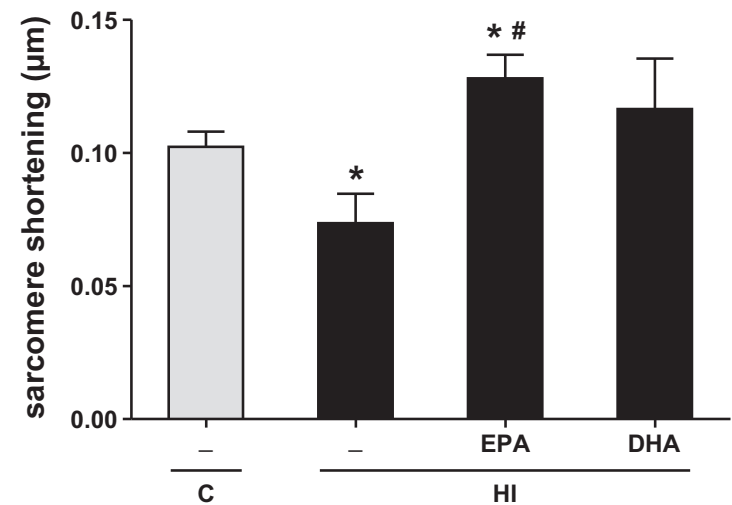

Fig. 6. Effect of $\omega-3$ PUFAs on peak sarcomere shortening. Cardiomyocytes were preincubated for $48 \mathrm{~h}$ in control medium (C) or in medium supplied with $100 \mathrm{nM}$ insulin (HI) in the absence or presence of $200 \mu \mathrm{M}$ EPA or DHA. Subsequently peak sarcomere shortening was recorded under $1 \mathrm{~Hz}$ and $5 \mathrm{~ms}$ of electrical pulsated cardiomyocytes. Results are represented as mean values \pm $\mathrm{SE}(n=6)$. ${ }^{*} P<0.05$ vs. control value; $\# P<0.05$ vs. value in the absence of $\omega-3$ PUFAs.

involved in the development of insulin resistance, namely persistent CD36 relocation to the sarcolemma. Our results are also consistent with results by Madonna and colleagues (30), who observed a decreased plasma membrane content of CD36 after treatment with EPA or DHA in human microvascular endothelial cells.

The fact that the EPA- or DHA-induced elevation of palmitate uptake was not paralleled by elevated presence of CD36 at the sarcolemma could indicate that EPA and DHA open alternative avenues for palmitate uptake, which bypass the CD36 transporter. One possibility could be that the presence of EPA or DHA alters the fluidity of the sarcolemma by incorporation into the phospholipid bilayer, allowing for increased uptake of palmitate through passive diffusion (19). Apparently, this was not the case, since blocking of CD36 during EPA exposure by specific anti-CD36 antibody almost totally prevented the palmitate uptake. Perhaps, in addition to their prevention of CD36 permanent relocation to sarcolemma, both EPA and DHA alter the bilayer organization around CD36, thereby increasing the LCFA transport function of this membrane protein.

Besides at the level of CD36, this study indicates that EPA is also able to influence cardiomyocyte fatty acid handling at the level of lipid breakdown via upregulation of ATGL. It has previously been shown that HI cultured cardiomyocytes display a twofold accumulation of intracellular triacylglycerol (5). Here we show that ATGL expression was not altered upon HI treatment. This might suggest that myocellular lipid accumulation in $\mathrm{HI}$ conditions is due to permanent CD36 translocation and increased fatty acid uptake, but not to a reduction in triacylglycerol hydrolysis. Yet, the ability of EPA to upregulate ATGL could contribute to the beneficial effect of this fatty acid to preserve insulin signaling in cardiomyocytes during conditions of lipid overload, i.e., via redirecting fatty acids from triacylglycerol storage towards mitochondrial $\beta$-oxidation. ATGL upregulation would downregulate not only triacylglycerol, but also diacylglycerol and ceramide levels, and thereby relieve the blockade of insulin signaling in cardiomyocytes during lipid overexposure.

Finally, impaired contractile function has been reported in isolated cardiomyocytes in insulin-resistant states, probably due to alterations in transsarcolemmal ion transport (38). The present observation that EPA (and probably DHA) improves contractile function of cardiomyocytes cultured under HI conditions is a novel finding, which should be explained in terms of the concomitantly improved insulin sensitivity, although determination of the cellular and molecular mechanisms involved requires further investigations.

Concluding remarks. In summary, the present study shows that EPA and DHA counteract the development of insulin resistance in isolated cardiomyocytes incubated under insulin resistance-evoking conditions by preserving the phosphorylation state of key proteins in the insulin signaling cascade and by preventing persistent relocation of CD36 to the sarcolemma. To our knowledge, this is the first study extending the beneficial effects of $\omega-3$ PUFAs to preservation of contractile function of the heart at the cellular level and in the context of insulin resistance.
A

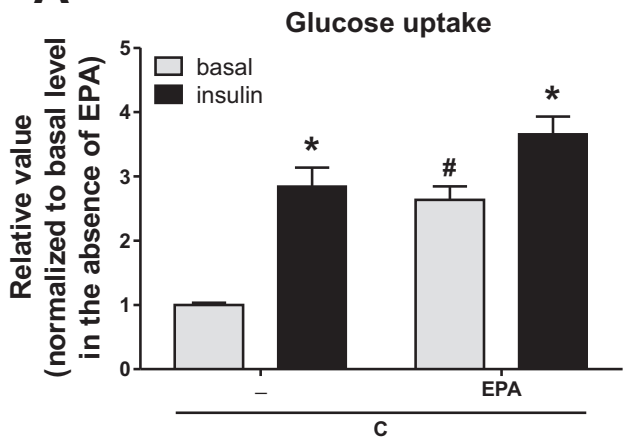

B

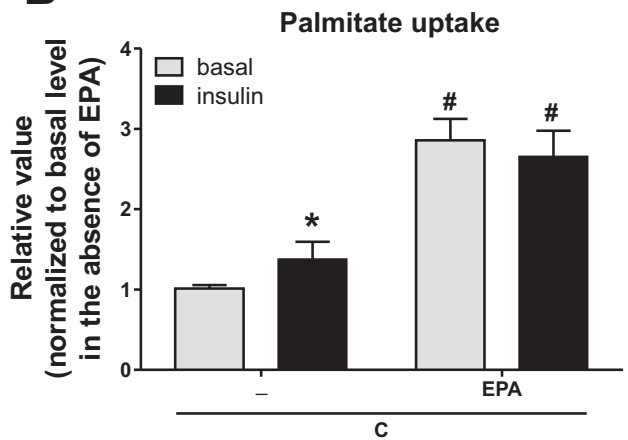

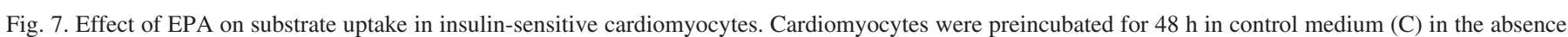

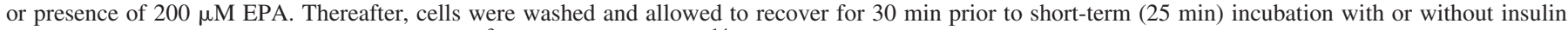

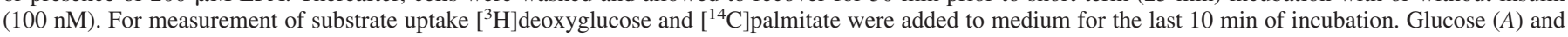

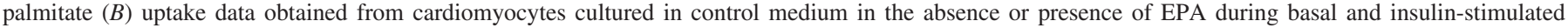

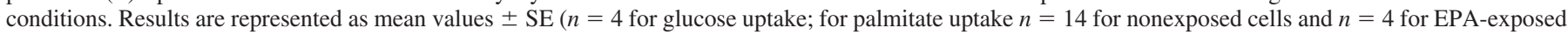
cells). $* P<0.05$ vs. basal value; \#P<0.05 vs. corresponding values in the absence of EPA. 
A

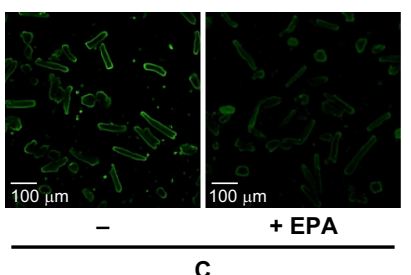

C
B

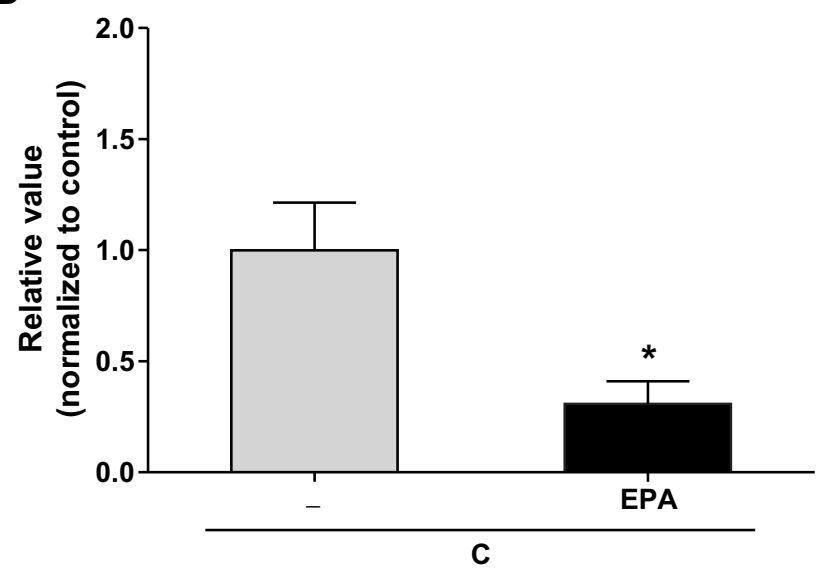

C

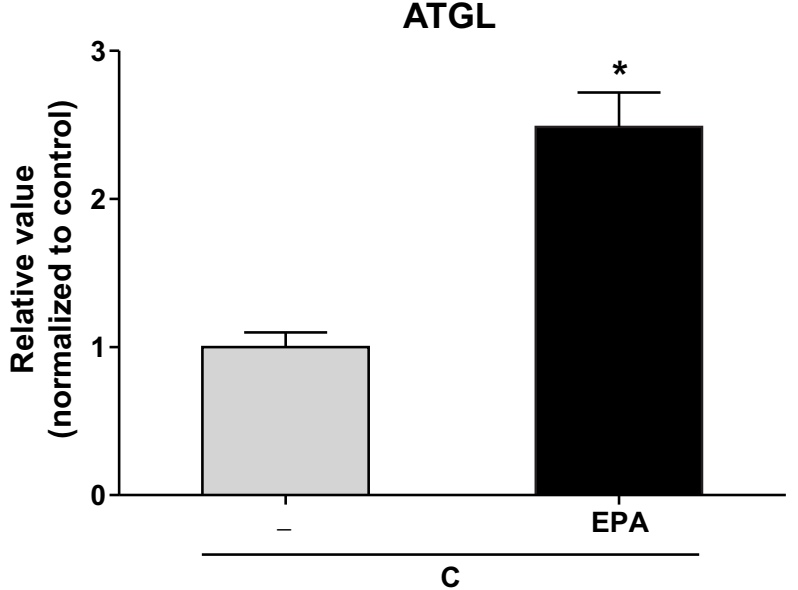

E

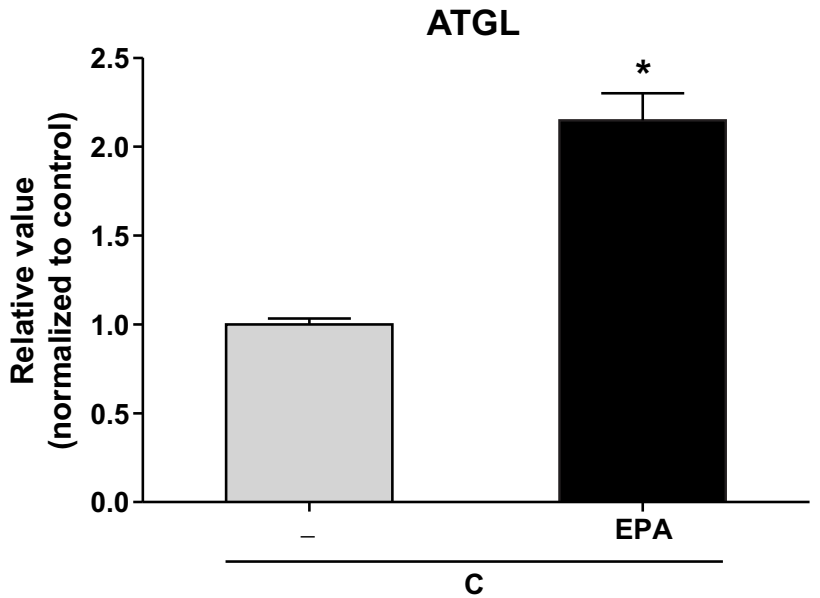

D

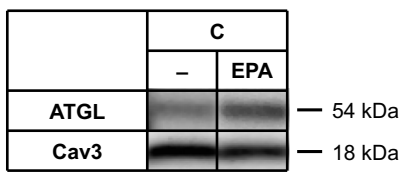

F

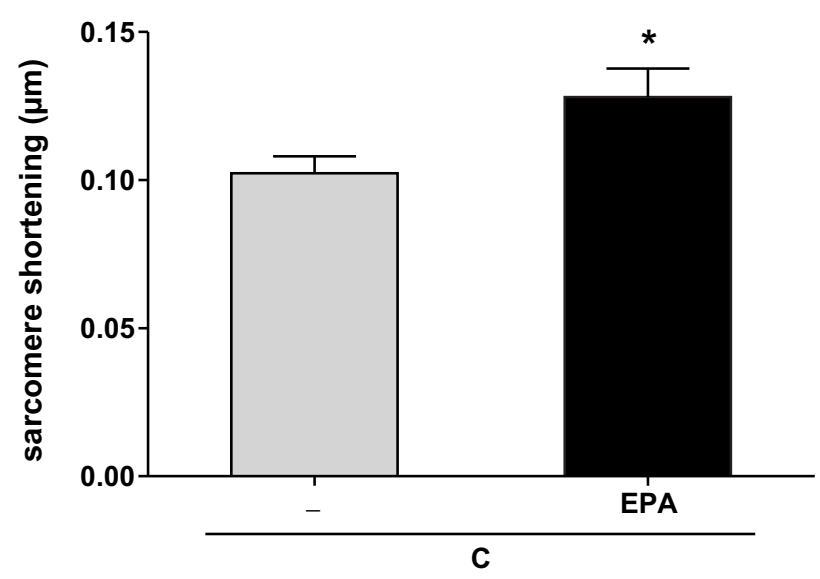

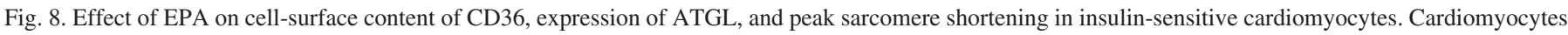

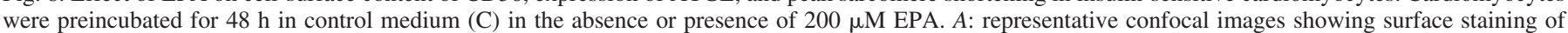

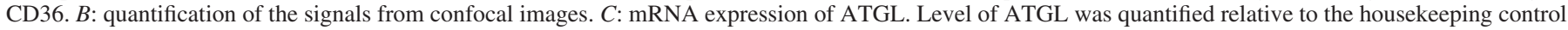

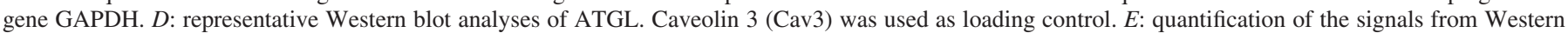

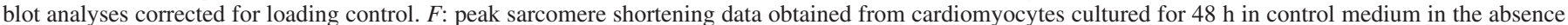
or presence of EPA. Results are represented as mean values $\pm \mathrm{SE}(n=3-6)$. ${ }^{*} P<0.05$ vs. value in the absence of EPA. 


\section{ACKNOWLEDGMENTS}

We thank Dr. D. Chanda and Dr. T. Lund for technical assistance with the AMPK and mRNA measurements and Prof. E. Aasum for useful comments during the preparation of the manuscript.

\section{GRANTS}

This work was supported by the Norwegian Diabetes Association, the Norwegian Heart Foundation, and Calanus AS, Troms $\varnothing$, Norway.

\section{DISCLOSURES}

No conflicts of interest, financial or otherwise, are declared by the author(s).

\section{AUTHOR CONTRIBUTIONS}

Author contributions: V.F., J.F.G., J.J.L., and T.S.L. conception and design of research; V.F., Y.A., N.T.H., and W.A.C. performed experiments; V.F., Y.A., and J.J.L. analyzed data; V.F., Y.A., J.J.L., and T.S.L. interpreted results of experiments; V.F. prepared figures; V.F. and T.S.L. drafted manuscript; V.F., Y.A., J.F.G., J.J.L., and T.S.L. edited and revised manuscript; V.F., Y.A., N.T.H., W.A.C., P.J.S., J.F.G., J.J.L., and T.S.L. approved final version of manuscript.

\section{REFERENCES}

1. Aas V, Rokling-Andersen MH, Kase ET, Thoresen GH, Rustan AC. Eicosapentaenoic acid (20:5 n-3) increases fatty acid and glucose uptake in cultured human skeletal muscle cells. J Lipid Res 47: 366-374, 2006.

2. Aasum E, Hafstad AD, Severson DL, Larsen TS. Age-dependent changes in metabolism, contractile function, and ischemic sensitivity in hearts from $d b / d b$ mice. Diabetes 52: 434-441, 2003.

3. Abel ED, O'Shea KM, Ramasamy R. Insulin resistance: metabolic mechanisms and consequences in the heart. Arterioscler Thromb Vasc Biol 32: 2068-2076, 2012.

4. Akinkuolie AO, Ngwa JS, Meigs JB, Djoussé L. Omega-3 polyunsaturated fatty acid and insulin sensitivity: a meta-analysis of randomized controlled trials. Clin Nutr 30: 702-707, 2011.

5. Angin Y, Steinbusch LK, Simons PJ, Greulich S, Hoebers NT, Douma $K$, van Zandvoort MA, Coumans WA, Wijnen W, Diamant $M$, Ouwens DM, Glatz JF, Luiken JJ. CD36 inhibition prevents lipid accumulation and contractile dysfunction in rat cardiomyocytes. Biochem $J$ 448: 43-53, 2012.

6. Bertrand L, Ginion A, Beauloye C, Hebert AD, Guigas B, Hue L, Vanoverschelde JL. AMPK activation restores the stimulation of glucose uptake in an in vitro model of insulin-resistant cardiomyocytes via the activation of protein kinase. Am J Physiol Heart Circ Physiol 291: H239-H250, 2006.

7. Bertrand L, Horman S, Beauloye C, Vanoverschelde JL. Insulin signalling in the heart. Cardiovasc Res 79: 238-248, 2008.

8. Chen J, Shearer GC, Chen Q, Healy CL, Beyer AJ, Nareddy VB, Gerdes AM, Harris WS, O'Connell TD, Wang D. Omega-3 fatty acids prevent pressure overload-induced cardiac fibrosis through activation of cyclic GMP/protein kinase G signaling in cardiac fibroblasts. Circulation 123: 584-593, 2011.

9. Coort SL, Bonen A, van der Vusse GJ, Glatz JF, Luiken JJ. Cardiac substrate uptake and metabolism in obesity and type-2 diabetes: role of sarcolemmal substrate transporters. Mol Cell Biochem 299: 5-18, 2007.

10. Desrois M, Sidell RJ, Gauguier D, King LM, Radda GK, Clarke K. Initial steps of insulin signaling and glucose transport are defective in the type 2 diabetic rat heart. Cardiovasc Res 61: 288-296, 2004.

11. Dobrzyn A, Dobrzyn P, Miyazaki M, Ntambi JM. Polyunsaturated fatty acids do not activate AMP-activated protein kinase in mouse tissues. Biochem Biophys Res Commun 332: 892-896, 2005.

12. Duda MK, O'Shea KM, Stanley WC. Omega-3 polyunsaturated fatty acid supplementation for the treatment of heart failure: mechanisms and clinical potential. Cardiovasc Res 84: 33-41, 2009.

13. Fedor D, Kelley DS. Prevention of insulin resistance by n-3 polyunsaturated fatty acids. Curr Opin Clin Nutr Metab Care 12: 138-146, 2009.

14. Fischer Y, Thomas J, Sevilla L, Muñoz P, Becker C, Holman G, Kozka IJ, Palacín M, Testar X, Kammermeier H, Zorzano A. Insulininduced recruitment of glucose transporter 4 (GLUT4) and GLUT1 in isolated rat cardiac myocytes. Evidence of the existence of different intracellular GLUT4 vesicle populations. J Biol Chem 272: 7085-7092, 1997.
15. Flachs P, Mohamed-Ali V, Horakova O, Rossmeisl M, HosseinzadehAttar MJ, Hensler M, Ruzickova J, Kopecky J. Polyunsaturated fatty acids of marine origin induce adiponectin in mice fed a high-fat diet. Diabetologia 49: 394-397, 2006.

16. Gabler NK, Radcliffe JS, Spencer JD, Webel DM, Spurlock ME. Feeding long-chain n-3 polyunsaturated fatty acids during gestation increases intestinal glucose absorption potentially via the acute activation of AMPK. J Nutr Biochem 20: 17-25, 2009.

17. Ginion A, Auquier J, Benton CR, Mouton C, Vanoverschelde JL, Hue L, Horman S, Beauloye C, Bertrand L. Inhibition of the mTOR/p70S6K pathway is not involved in the insulin-sensitizing effect of AMPK on cardiac glucose uptake. Am J Physiol Heart Circ Physiol 301: H469H477, 2011.

18. Greulich S, de Wiza DH, Preilowski S, Ding Z, Mueller H, Langin D, Jaquet K, Ouwens DM, Eckel J. Secretory products of guinea pig epicardial fat induce insulin resistance and impair primary adult rat cardiomyocyte function. J Cell Mol Med 15: 2399-2410, 2011.

19. Hamilton JA, Guo W, Kamp F. Mechanism of cellular uptake of long-chain fatty acids: Do we need cellular proteins? Mol Cell Biochem 239: 17-23, 2002.

20. Huisamen B. Protein kinase B in the diabetic heart. Mol Cell Biochem 249: 31-38, 2003.

21. Kalupahana NS, Claycombe KJ, Moustaid-Moussa N. (n-3) Fatty acids alleviate adipose tissue inflammation and insulin resistance: mechanistic insights. Adv Nutr 2: 304-316, 2011.

22. Kalupahana NS, Claycombe K, Newman SJ, Stewart T, Siriwardhana N, Matthan N, Lichtenstein AH, Moustaid-Moussa N. Eicosapentaenoic acid prevents and reverses insulin resistance in high-fat diet-induced obese mice via modulation of adipose tissue inflammation. J Nutr 140: 1915-1922, 2010.

23. Kopecky J, Rossmeisl M, Flachs P, Kuda O, Brauner P, Jilkova Z, Stankova B, Tvrzicka E, Bryhn M. n-3 PUFA: bioavailability and modulation of adipose tissue function. Proc Nutr Soc 68: 361-369, 2009.

24. Kramer HF, Witczak CA, Fujii N, Jessen N, Taylor EB, Arnolds DE, Sakamoto K, Hirshman MF, Goodyear LJ. Distinct signals regulate AS160 phosphorylation in response to insulin, AICAR, and contraction in mouse skeletal muscle. Diabetes 55: 2067-2076, 2006.

25. Le Foll C, Corporeau C, Le Guen V, Gouygou JP, Bergé JP, Delarue J. Long-chain n-3 polyunsaturated fatty acids dissociate phosphorylation of Akt from phosphatidylinositol 3'-kinase activity in rats. Am J Physiol Endocrinol Metab 292: E1223-E1230, 2007.

26. Lorente-Cebrián S, Bustos M, Marti A, Martinez JA, Moreno-Aliaga MJ. Eicosapentaenoic acid stimulates AMP-activated protein kinase and increases visfatin secretion in cultured murine adipocytes. Clin Sci (Lond) 117: 243-249, 2009.

27. Lorente-Cebrián S, Costa AG, Navas-Carretero S, Zabala M, Martínez JA, Moreno-Aliaga MJ. Role of omega-3 fatty acids in obesity, metabolic syndrome, and cardiovascular diseases: a review of the evidence. J Physiol Biochem 69: 633-651, 2013.

28. Luiken JJ, Koonen DP, Willems J, Zorzano A, Becker C, Fischer Y, Tandon NN, Van Der Vusse GJ, Bonen A, Glatz JF. Insulin stimulates long-chain fatty acid utilization by rat cardiac myocytes through cellular redistribution of FAT/CD36. Diabetes 51: 3113-3119, 2002.

29. Luiken JJ, van Nieuwenhoven FA, America G, van der Vusse GJ, Glatz JF. Uptake and metabolism of palmitate by isolated cardiac myocytes from adult rats: involvement of sarcolemmal proteins. J Lipid Res 38: 745-758, 1997.

30. Madonna R, Salerni S, Schiavone D, Glatz JF, Geng YJ, De Caterina R. Omega-3 fatty acids attenuate constitutive and insulin-induced CD36 expression through a suppression of PPAR alpha/gamma activity in microvascular endothelial cells. Thromb Haemost 106: 500-510, 2011.

31. Nettleton JA, Katz R. n-3 long-chain polyunsaturated fatty acids in type 2 diabetes: a review. J Am Diet Assoc 105: 428-440, 2005.

32. Oh DY, Talukdar S, Bae EJ, Imamura T, Morinaga H, Fan W, Li P, Lu WJ, Watkins SM, Olefsky JM. GPR120 is an omega-3 fatty acid receptor mediating potent anti-inflammatory and insulin-sensitizing effects. Cell 142: 687-698, 2010.

33. Oliver E, McGillicuddy FC, Harford KA, Reynolds CM, Phillips CM, Ferguson JF, Roche HM. Docosahexaenoic acid attenuates macrophageinduced inflammation and improves insulin sensitivity in adipocytesspecific differential effects between LC n-3 PUFA. J Nutr Biochem 23: 1192-1200, 2012.

34. O'Shea KM, Chess DJ, Khairallah RJ, Hecker PA, Lei B, Walsh K, Des Rosiers C, Stanley WC. Omega-3 polyunsaturated fatty acids pre- 
vent pressure overload-induced ventricular dilation and decrease in mitochondrial enzymes despite no change in adiponectin. Lipids Health Dis 9: $95,2010$.

35. Ouwens DM, Boer C, Fodor M, de Galan P, Heine RJ, Maassen JA, Diamant M. Cardiac dysfunction induced by high-fat diet is associated with altered myocardial insulin signalling in rats. Diabetologia 48: 1229 1237, 2005.

36. Ouwens DM, Diamant M, Fodor M, Habets DD, Pelsers MM, El Hasnaoui M, Dang ZC, van den Brom CE, Vlasblom R, Rietdijk A, Boer C, Coort SL, Glatz JF, Luiken JJ. Cardiac contractile dysfunction in insulin-resistant rats fed a high-fat diet is associated with elevated CD36-mediated fatty acid uptake and esterification. Diabetologia 50: 1938-1948, 2007.

37. Park SY, Cho YR, Kim HJ, Higashimori T, Danton C, Lee MK, Dey A, Rothermel B, Kim YB, Kalinowski A, Russell KS, Kim JK. Unraveling the temporal pattern of diet-induced insulin resistance in individual organs and cardiac dysfunction in C57BL/6 mice. Diabetes 54: 3530-3540, 2005.

38. Ren J, Sowers JR, Walsh MF, Brown RA. Reduced contractile response to insulin and IGF-I in ventricular myocytes from genetically obese Zucker rats. Am J Physiol Heart Circ Physiol 279: H1708-H1714, 2000.

39. Rodrigues B, Cam MC, McNeill JH. Metabolic disturbances in diabetic cardiomyopathy. Mol Cell Biochem 180: 53-57, 1998.

40. Russell RR 3rd, Bergeron R, Shulman GI, Young LH. Translocation of myocardial GLUT-4 and increased glucose uptake through activation of AMPK by AICAR. Am J Physiol Heart Circ Physiol 277: H643-H649, 1999.

41. Sano H, Kane S, Sano E, Miinea CP, Asara JM, Lane WS, Garner CW, Lienhard GE. Insulin-stimulated phosphorylation of a Rab GTPaseactivating protein regulates GLUT4 translocation. J Biol Chem 278: 14599-14602, 2003

42. Saraswathi V, Morrow JD, Hasty AH. Dietary fish oil exerts hypolipidemic effects in lean and insulin sensitizing effects in obese LDLR-/mice. J Nutr 139: 2380-2386, 2009.

43. Smith GI, Atherton P, Reeds DN, Mohammed BS, Rankin D, Rennie MJ, Mittendorfer B. Omega-3 polyunsaturated fatty acids augment the muscle protein anabolic response to hyperinsulinaemia-hyperaminoaci- daemia in healthy young and middle-aged men and women. Clin Sci (Lond) 121: 267-278, 2011.

44. Spencer M, Finlin BS, Unal R, Zhu B, Morris AJ, Shipp LR, Lee J, Walton RG, Adu A, Erfani R, Campbell M, McGehee RE Jr, Peterson CA, Kern PA. Omega-3 fatty acids reduce adipose tissue macrophages in human subjects with insulin resistance. Diabetes 62: 1709-1717, 2013.

45. Storlien LH, Kraegen EW, Chisholm DJ, Ford GL, Bruce DG, Pascoe WS. Fish oil prevents insulin resistance induced by high-fat feeding in rats. Science 237: 885-888, 1987.

46. Suchankova G, Tekle M, Saha AK, Ruderman NB, Clarke SD, Gettys TW. Dietary polyunsaturated fatty acids enhance hepatic AMP-activated protein kinase activity in rats. Biochem Biophys Res Commun 326: 851-858, 2005.

47. Tsitouras PD, Gucciardo F, Salbe AD, Heward C, Harman SM. High omega-3 fat intake improves insulin sensitivity and reduces CRP and IL6, but does not affect other endocrine axes in healthy older adults. Horm Metab Res 40: 199-205, 2008.

48. van Oort MM, van Doorn JM, Bonen A, Glatz JF, van der Horst DJ, Rodenburg KW, Luiken JJ. Insulin-induced translocation of CD36 to the plasma membrane is reversible and shows similarity to that of GLUT4. Biochim Biophys Acta 1781: 61-71, 2008.

49. Wiza C, Nascimento EB, Ouwens DM. Role of PRAS40 in Akt and mTOR signaling in health and disease. Am J Physiol Endocrinol Metab 302: E1453-E1460, 2012.

50. Wright JJ, Kim J, Buchanan J, Boudina S, Sena S, Bakirtzi K, Ilkun O, Theobald HA, Cooksey RC, Kandror KV, Abel ED. Mechanisms for increased myocardial fatty acid utilization following short-term high-fat feeding. Cardiovasc Res 82: 351-360, 2009.

51. Wu JH, Cahill LE, Mozaffarian D. Effect of fish oil on circulating adiponectin: a systematic review and meta-analysis of randomized controlled trials. J Clin Endocrinol Metab 98: 2451-2459, 2013.

52. Zhu Y, Pereira RO, O'Neill BT, Riehle C, Ilkun O, Wende AR, Rawlings TA, Zhang YC, Zhang Q, Klip A, Shiojima I, Walsh K, Abel ED. Cardiac PI3K-Akt impairs insulin-stimulated glucose uptake independent of mTORC1 and GLUT4 translocation. Mol Endocrinol 27: 172-184, 2013. 